\title{
Controlling Root-Knot Nematode, Meloidogyne incognita Infecting \\ Field Dry Pea (Pisum sativum L.) by Certain Moringa Residues and Extracts
}

\author{
Mahmoud M.A. Youssef* and Wafaa M.A. El-Nagdi \\ Plant Pathology Dept., Nematology Laboratory, National Research Centre, Dokki, Post code 12622 \\ Giza, Egypt \\ *Corresponding author email: myoussef_2003@yahoo.com
}

Received: 12 June 2021

Revised: 29 June 2021

Accepted: 2 July 2021

\begin{abstract}
Chemical nematicides have potential for risks and pollution to the environment and human health. Hence, this promoted the needs to use alternatives from certain medical plants. This research was designated to evaluate certain moringa plant part residues with their aqueous extracts and seed oil suspension for controlling root-knot nematode, M. incognita on field dry pea (Pisum sativum L.) under screen house conditions. On the basis of mean of total percentages of nematode reduction for each parameter, it was found that dry root powder registered the highest mean of total percentages of reduction $(81.6 \%)$ followed by those of mashed fresh leaves $(80.8 \%)$, seeds powder $(79.5 \%)$ and dry leaves $(76.4 \%)$. When using extracts of moringa residues, it was noticed that aqueous extract of seeds powder achieved the highest percentage nematode reduction $(81.1 \%)$ followed by extract of dry leaves powder $(80.8 \%)$, extract of dry root powder $(80.5 \%)$. The least reduction $(74.2 \%)$ was caused by seed oil suspension Number of galls was reduced while number of nodules was increased according to the tested materials. Consequently, the different treatments improved plant growth and yield parameters.
\end{abstract}

Keywords: Controlling, Meloidogyne incognita, moringa residues and extracts, field dry pea.

\section{INTRODUCTION}

As cited by Ramadan and Soliman (2020), root-knot nematode, Meloidogyne incognita is considered one of the major plant parasites causing damage to many agricultural crops. The using of chemical nematicides has potential for risks and pollution to the environment and human health. On this basis, the search for alternatives to chemical nematicides from certain medicinal plants was promoted. Among these plants, moringa (Moringa oleifera) was used to control root-knot nematode (Lockett et al., 2000; Anwar and Rashid, 2007). Seed extract of M. oleifera has been found to have potent substances to microbes (Kebreab et al., 2005; Jamil et al., 2007). Jasy and Koshy (1992) reported that leaf extract of moringa plant was found to reduce Radopholus similis. Sowley et al.(2014) tested moringa leaf powder for controlling Meloidogyne spp. in sweet pepper (Capsicum annuum L.). They found that the concentration of $80 \mathrm{~g} / \mathrm{L}$ of moringa leaf powder reduced gall index and nematode population in soil and consequently promoted plant growth criteria. 
Claudius-Cole et al. (2010) reported that $M$. oleifera inhibited nematode egg hatching and juvenile survival of $M$. incognita on cowpea. In addition, El-Nagdi and Youssef (2015) reported that aqueous extract of moringa dry leaves reduced number of galling and reproduction of root-knot nematode on sugar beet plants, which consequently improved vegetative growth parameters.

The present investigation was designed to evaluate the effect of moringa plant parts residues and seed oil suspension for controlling root-knot nematode, $M$. incognita on field pea.

\section{MATERIALS AND METHODS}

\section{Source of the test plant}

Field dry pea (Pisum sativum L.) cv. Concessa seeds were obtained from Vegetable Research Institute, Agricultural Research Center, Dokki, Giza, Egypt.

\section{Source of the tested materials}

Egyptian Scientific Society of Moringa (ESSM) in National Research Centre, Egypt was the source of the tested moringa (Moringa oleifera Lam.) materials including leaves, seeds and roots dry powders, mashed fresh leaves and seed oil.

\section{Screen house experiment}

Under screen house conditions, four field pea seeds were sown in pots, 25-cm-diam. containing $3 \mathrm{~kg}$ solarized sandy loam soil (1:1). One week before sowing, a $5 \mathrm{~g}$ of each plant residues previously mentioned was added in each pot by thoroughly mixing with soil and watered daily to help their decomposition in soil. Also, aqueous extracts were prepared by soaking a 5- $\mathrm{g}$ of each of the previous plant residues in 100-ml distilled water which for $72 \mathrm{hr}$. at lab. temperature, then passed through $15-\mathrm{mm}$. diam. Whatman No.1 filter paper for filtration. The resulted plant part filtrates at the same rate $(20-\mathrm{ml}$ per pot), were added in each pot before planting. Also, moringa seed oil extract (suspension 5\%) was prepared by mixing 5-m oil with $100-\mathrm{ml}$ distilled water with drops of tween to help mixing and added at the rate of 20-ml per pot before planting. One week after seed emergence, plantlets in each pot were thinned to two plantlets in each pot, A level of 1,000 second stage juveniles $\left(\mathrm{J}_{2}\right)$ of root-knot nematode, $M$. incognita reared on susceptible tomato cultivar Super Strain B was used as inoculum to each pot. This was done by adding suspension of juveniles in 4 holes around plant roots in each pot. Five replicates for each treatment and control were considered. The compound, Okadean (containing nitrogen-fixing bacterium called Rhizobium leguminosarum) at recommended rate was added to pots in all treatments. A completely randomized design was used to organize pots on a bench at $18 \pm 5{ }^{\circ} \mathrm{C}$. Then, plant irrigation was carried out as needed.

Three months after the date of nematode inoculation, plants of pea were gently removed and roots were cleaned thoroughly with running water to devoid debris, then, were cut in two portions. Egg mass and gall numbers were counted in one portion. Incubation method (Young 1954) was used to extract $\mathbf{J}_{2}$ from eggs found in the form of masses in the second portion of roots. The soil population of $\mathrm{J}_{2} \mathrm{~S}$ per pot were extracted using the method described by Barker (1985) and counted. Plant growth 
parameters of field pea including shoot length $(\mathrm{cm})$, fresh and dry weights $(\mathrm{g})$ of shoots and roots $(\mathrm{g})$ were measured. Also, yield as number and weight of pods $(\mathrm{g})$ was estimated.

\section{Statistical analysis}

Means of total percentages of nematode reduction, plant growth and yield increases were calculated to compare between treatments as follows: sum percentages of all parameters of each treatment/number of these parameters $\times 100$. To check the significant differences among treatments, data were processed statistically by analysis of variance (ANOVA) test. Treatment means at 5\% level of probability were compared by Duncan's Multiple Range Test as reported by Snedecor and Cochran (1989). This was done by Computer Statistics (COSTAT) software.

\section{RESULTS}

\section{Effect of the tested moringa residues on galling and reproduction of Meloidogyne incognita}

Data in Table (1) illustrated the different effects of the various moringa residues on $M$. incognita reproductive parameters in soil and roots as well as number of galls and number of bacterial nodules on roots of field pea. On the basis of mean of total percentages of nematode reduction for each treatment, it was found that dry root powder registered the highest percentage reduction $(81.6 \%)$ followed by those of mashed fresh leaves $(80.8 \%)$,seeds powder(79.5\%) and dry leaves $(76.4 \%)$. Reduction in number of galls behaved an independent pattern as seeds and dry root powder have equal percentage reduction $(65.2 \%)$ followed by dry and fresh leaves have equal percentage $(60.9 \%)$. Number of bacterial nodules increased by $14.18 \%$ by using dry leaves powder followed by dry root powder $(11.1 \%)$. The least percentage increase (3.7) was caused by using seeds powder.

\section{Effect of the tested moringa residues on vegetative and yield parameters}

Data in Table (2) illustrated effect of the different moringa residues on vegetative and yield parameters of field pea infected by $M$. incognita. On the basis of the mean of total percentages of plant growth and yield increases for each treatment, it was found that seeds powder registered the highest mean of total percentage increase $(30.2 \%)$ followed by those of dry root powder (24.5\%), mashed fresh leaves $(24.1 \%)$ and dry leaves powder $(20.5 \%)$.

\section{Effect of the tested moringa extracts and seed oil suspension on galling and reproduction of Meloidogyne incognita}

When using extracts of moringa residues, it was noticed that aqueous extract of seeds powder achieved the highest mean of percentages of nematode reduction $(81.1 \%)$ followed by extract of dry leaves powder $(80.8 \%)$, extract of dry root powder $(80.5 \%)$. The least one (74.2\%) was obtained by seed oil suspension (Table 3). 
Table 1: Effect of moringa residues on root-knot nematode, Meloidogyne incognita infecting field dry pea and bacterial nodules.

\begin{tabular}{|c|c|c|c|c|c|c|c|c|c|c|c|}
\hline \multirow[t]{2}{*}{ Treatments } & \multicolumn{8}{|c|}{ Galling and reproduction of $M$. incognita } & \multicolumn{3}{|c|}{ Bacterial nodules } \\
\hline & $\begin{array}{l}\text { No.J }_{2} \\
\text { in soil }\end{array}$ & $\begin{array}{l}\% \\
\text { Red. } \\
*\end{array}$ & $\begin{array}{l}\text { No. } \\
\mathrm{J}_{2} / \text { root }\end{array}$ & $\%$ Red. & $\begin{array}{l}\text { No. egg } \\
\text { masses/ } \\
\text { root }\end{array}$ & $\%$ Red. & $\begin{array}{l}\text { Average } \\
\text { total\% } \\
\text { nemato } \\
\text { de red. }\end{array}$ & $\begin{array}{l}\text { No. } \\
\text { galls/ } \\
\text { root }\end{array}$ & Red. & No. & $\begin{array}{l}\% \\
\text { Inc. } * *\end{array}$ \\
\hline $\begin{array}{l}\text { Dry leaves powder } \\
(5 \mathrm{~g} / \text { pot })\end{array}$ & $450 \mathrm{~b}$ & 88.8 & $35 c$ & 90.3 & $7 \mathrm{~b}$ & 50.0 & 76.4 & $9 \mathrm{~b}$ & 60.9 & $31 \mathrm{a}$ & 14.8 \\
\hline $\begin{array}{l}\text { Mashed fresh leaves } \\
(5 \mathrm{~g} / \text { pot })\end{array}$ & $600 \mathrm{~b}$ & 85.0 & $50 \mathrm{bc}$ & 86.1 & $4 \mathrm{c}$ & 71.4 & 80.8 & $9 b$ & 60.9 & $29 a$ & 7.4 \\
\hline $\begin{array}{l}\text { Seeds powder } \\
(5 \mathrm{~g} / \text { pot })\end{array}$ & $450 \mathrm{~b}$ & 88.8 & $53 b$ & 85.3 & $5 \mathrm{c}$ & 64.3 & 79.5 & $8 \mathrm{~b}$ & 65.2 & $28 \mathrm{a}$ & 3.7 \\
\hline $\begin{array}{l}\text { Dry root powder } \\
\text { (5g/pot) }\end{array}$ & $625 b$ & 84.4 & $40 \mathrm{bc}$ & 88.9 & $4 c$ & 71.4 & 81.6 & $8 b$ & 65.2 & $30 a$ & 11.1 \\
\hline Control & $4000 a$ & 0.0 & $360 \mathrm{a}$ & 0.0 & $14 a$ & 0.0 & 0.0 & $23 a$ & 0 & $27 \mathrm{a}$ & 0.0 \\
\hline
\end{tabular}

Each value is an average of five replicates.

Different letter (s) of each column is significantly different according to Duncan's Multiple Range test at 0.05 level.

*Reduction (Red.) \% = Control- Treated X 100

$* *$ Increase (Inc.) $\%=\underline{\text { Treated }- \text { Control X } 100}$

Control 
Table 2: Effect of moringa residues on vegetative parameters and yield of field dry pea infected by root-knot nematode, Meloidogyne incognita.

\begin{tabular}{|c|c|c|c|c|c|c|c|c|}
\hline \multirow[b]{2}{*}{ Treatments } & \multicolumn{3}{|c|}{ Shoot parameters } & \multicolumn{2}{|c|}{ Root parameters } & \multicolumn{2}{|c|}{ Pod parameters } & \multirow{2}{*}{$\begin{array}{l}\text { Average } \\
\text { total \% } \\
\text { plant } \\
\text { growth \& } \\
\text { yield } \\
\text { increase }\end{array}$} \\
\hline & $\begin{array}{c}\text { Length } \\
(\mathrm{cm})\end{array}$ & $\begin{array}{l}\text { Fresh } \\
\text { weight } \\
\text { (g) }\end{array}$ & $\begin{array}{l}\text { Dry } \\
\text { weight } \\
(\mathrm{g})\end{array}$ & $\begin{array}{l}\text { Fresh } \\
\text { weight } \\
\text { (g) }\end{array}$ & $\begin{array}{l}\text { Dry } \\
\text { weight } \\
\text { (g) }\end{array}$ & $\begin{array}{c}\text { No. of } \\
\text { pods/ } \\
\text { root }\end{array}$ & $\begin{array}{l}\text { Weight } \\
(\mathrm{g})\end{array}$ & \\
\hline $\begin{array}{l}\text { Dry leaves } \\
\text { Powder(5g/pot) }\end{array}$ & $\begin{array}{l}52.0 \mathrm{a} \\
(25.0)^{*}\end{array}$ & $\begin{array}{l}16.3 \mathrm{~b} \\
(23.5)\end{array}$ & $\begin{array}{l}2.5 \mathrm{ab} \\
(4.2)\end{array}$ & $\begin{array}{l}2.7 \mathrm{~b} \\
(0.0)\end{array}$ & $\begin{array}{l}0.9 \mathrm{a} \\
(50.0)\end{array}$ & $\begin{array}{l}4 \mathrm{a} \\
(0.0)\end{array}$ & $\begin{array}{l}7.6 \mathrm{ab} \\
(40.7)\end{array}$ & 20.5 \\
\hline $\begin{array}{l}\text { Mashed fresh } \\
\text { leaves }(5 \mathrm{~g} / \text { pot })\end{array}$ & $\begin{array}{l}52.8 \mathrm{a} \\
(26.7)\end{array}$ & $\begin{array}{l}18.3 \mathrm{a} \\
(38.6)\end{array}$ & $\begin{array}{l}2.9 \mathrm{a} \\
(20.8)\end{array}$ & $\begin{array}{l}2.9 \mathrm{ab} \\
(7.4)\end{array}$ & $\begin{array}{l}0.6 \mathrm{~b} \\
(0.0)\end{array}$ & $\begin{array}{l}5 \mathrm{a} \\
(25.0)\end{array}$ & $\begin{array}{l}8.1 \mathrm{a} \\
(50.0)\end{array}$ & - \\
\hline $\begin{array}{l}\text { Seeds powder } \\
(5 \mathrm{~g} / \text { pot })\end{array}$ & $\begin{array}{l}51.8 \mathrm{ab} \\
(24.5)\end{array}$ & $\begin{array}{l}15.9 \mathrm{~b} \\
(20.5)\end{array}$ & $\begin{array}{l}2.5 \mathrm{ab} \\
(4.2)\end{array}$ & $\begin{array}{l}3.1 \mathrm{a} \\
(14.8)\end{array}$ & $\begin{array}{l}1.1 \mathrm{a} \\
(83.3)\end{array}$ & $\begin{array}{l}5 \mathrm{a} \\
(25.0\end{array}$ & $\begin{array}{l}7.5 \mathrm{ab} \\
(38.9)\end{array}$ & $-\overline{30.2}$ \\
\hline $\begin{array}{l}\text { Dry root } \\
\text { powder }(5 \mathrm{~g} / \text { pot })\end{array}$ & $\begin{array}{l}48.8 \mathrm{~b} \\
(17.3)\end{array}$ & $\begin{array}{l}14.5 \mathrm{c} \\
(9.8)\end{array}$ & $\begin{array}{l}2.6 \mathrm{ab} \\
(8.3)\end{array}$ & $\begin{array}{l}3.1 \mathrm{a} \\
(14.8)\end{array}$ & $\begin{array}{l}1.0 \mathrm{a} \\
(66.7)\end{array}$ & $\begin{array}{l}5 \mathrm{a} \\
(25.0)\end{array}$ & $\begin{array}{l}7.0 \mathrm{~b} \\
(29.6)\end{array}$ & - \\
\hline Control & $\begin{array}{l}41.6 c \\
(0.0)\end{array}$ & $\begin{array}{l}13.2 \mathrm{~d} \\
(0.0)\end{array}$ & $\begin{array}{l}2.4 \mathrm{~b} \\
(0.0)\end{array}$ & $\begin{array}{l}2.7 \mathrm{~b} \\
(0.0)\end{array}$ & $\begin{array}{l}0.6 \mathrm{~b} \\
(0.0)\end{array}$ & $\begin{array}{l}4 \mathrm{a} \\
(0.0)\end{array}$ & $\begin{array}{l}5.4 \mathrm{c} \\
(0.0)\end{array}$ & $\overline{0} .0$ \\
\hline
\end{tabular}

Each value is an average of five replicates.

Different letter (s) of each column is significantly different according to Duncan's Multiple Range test at $p \leq 0.05$ level

Values between parentheses indicate the percentages increase of plant growth and yield criteria

*Increase (Inc.) $\%=$ Treated - Control X 100

Control

Extracts of dry leaves, mashed leaves and dry root powders were equal in reducing number of galls $(65.2 \%)$. The least one was detected by oil suspension. Number of nodules were equally increased by using extracts of mashed leaves and dry root powder $(11.1 \%)$. The least one was determined by extract of dry leaves powder $(3.7 \%)$ (Table 3$)$.

\section{Effect of the tested moringa extracts and oil suspension on plant growth and yield parameters}

As for plant growth and yield, it was noticed that dry root powder recorded the highest mean of total percentages of plant growth and yield increases (39.2\%) followed by those of seeds powder $(38.3 \%)$, seed oil suspension $(35.1 \%)$. The least one $(20.1 \%)$ was caused by dry leaves powder (Table 4$)$.

\section{DISCUSSION}

In this study, moringa residues either as mash, powder, extract or oil suspension inhibited nematode galling and reproduction and increased plant growth and yield criteria of field pea infected by root-knot nematode, $M$. incognita. As cited by Sowley et al. (2014), the high content of certain oxygenated compounds which has lipophilic characteristics in moringa leaf powder may explain its effect on nematode. 
Table 3: Effect of moringa residues extracts on root-knot nematode, Meloidogyne incognita infecting field dry pea and bacterial nodules.

\begin{tabular}{|c|c|c|c|c|c|c|c|c|c|c|c|}
\hline \multirow[t]{2}{*}{ Treatments } & \multicolumn{7}{|c|}{ Galling and reproduction of $M$. incognita } & & \multicolumn{3}{|c|}{ Bacterial nodules } \\
\hline & $\begin{array}{c}\text { No. of } \\
\mathrm{J}_{2} \\
\text { in soil }\end{array}$ & $\begin{array}{l}\% \\
\text { Red.* }\end{array}$ & $\begin{array}{l}\text { No. of } \\
J_{2} \text { per } \\
\text { root }\end{array}$ & $\%$ Red. & $\begin{array}{l}\text { No. of egg } \\
\text { masses/ } \\
\text { root }\end{array}$ & $\begin{array}{c}\% \\
\text { Red. }\end{array}$ & $\begin{array}{l}\text { Average } \\
\text { total \% } \\
\text { nematode } \\
\text { red. }\end{array}$ & $\begin{array}{l}\text { No. of galls } \\
\text { per root }\end{array}$ & $\begin{array}{l}\% \\
\text { Red. }\end{array}$ & No. & $\%$ Inc. $* *$ \\
\hline $\begin{array}{l}\text { Dry leaves powder } \\
\text { extract }(5 \mathrm{~g} / 100 \mathrm{ml})\end{array}$ & $1000 \mathrm{~b}$ & 75.0 & $40 \mathrm{c}$ & 88.9 & $3 b$ & 78.6 & 80.8 & $8 c$ & 65.2 & $28 \mathrm{ab}$ & 3.7 \\
\hline $\begin{array}{l}\text { Mashed fresh leaves } \\
(5 \mathrm{~g} / 100 \mathrm{ml})\end{array}$ & $1050 \mathrm{~b}$ & 73.8 & $20 d$ & 94.4 & $5 b$ & 64.3 & 77.5 & $8 \mathrm{c}$ & 65.2 & $30 \mathrm{a}$ & 11.1 \\
\hline $\begin{array}{l}\text { Seeds powder } \\
\operatorname{extract}(5 \mathrm{~g} / 100 \mathrm{ml})\end{array}$ & $800 \mathrm{c}$ & 80.0 & $30 \mathrm{~cd}$ & 91.7 & $4 b$ & 71.4 & 81.0 & $9 \mathrm{bc}$ & 60.9 & $29 a b$ & 7.4 \\
\hline $\begin{array}{l}\text { Dry root powder } \\
\operatorname{extract}(5 \mathrm{~g} / 100 \mathrm{ml})\end{array}$ & $750 \mathrm{~cd}$ & 81.3 & $40 \mathrm{c}$ & 88.9 & $4 b$ & 71.4 & 80.5 & $8 c$ & 65.2 & $30 \mathrm{a}$ & 11.1 \\
\hline Control & $4000 \mathrm{a}$ & 0.0 & $360 \mathrm{a}$ & 0.0 & $14 \mathrm{a}$ & 0.0 & 0.0 & $23 a$ & 0.0 & $27 b$ & 0.0 \\
\hline
\end{tabular}

Each value is an average of five replicates

Different letter (s) of each column is significantly different according to Duncan's Multiple Range test at $\mathrm{p} \leq 0.05$ level.

*Reduction (Red.) $\%=\underline{\text { Control- Treated X } 100}$

$$
\text { Control }
$$

**Increase (Inc.) $\%=$ Treated - Control X 100

$$
\text { Control }
$$


Table 4: Effect of moringa residues extracts on vegetative parameters and yield of field dry pea infected by root-knot nematode, Meloidogyne incognita.

\begin{tabular}{|c|c|c|c|c|c|c|c|c|}
\hline \multirow[b]{2}{*}{ Treatments } & \multicolumn{3}{|c|}{ Shoot parameters } & \multicolumn{2}{|c|}{ Root parameters } & \multicolumn{2}{|c|}{ Pod parameters } & \multirow{2}{*}{$\begin{array}{l}\text { Average } \\
\text { total \% } \\
\text { plant } \\
\text { growth \& } \\
\text { yield } \\
\text { increase }\end{array}$} \\
\hline & $\begin{array}{l}\text { Length } \\
(\mathrm{cm})\end{array}$ & $\begin{array}{c}\text { Fresh } \\
\text { weight } \\
(\mathrm{g})\end{array}$ & $\begin{array}{c}\text { Dry } \\
\text { weight } \\
\text { (g) }\end{array}$ & $\begin{array}{c}\text { Fresh } \\
\text { weight } \\
\text { (g) }\end{array}$ & $\begin{array}{c}\text { Dry } \\
\text { weight } \\
(\mathrm{g})\end{array}$ & $\begin{array}{l}\text { No. } \\
\text { pod/ } \\
\text { root }\end{array}$ & $\begin{array}{l}\text { Weight } \\
(\mathrm{g})\end{array}$ & \\
\hline $\begin{array}{l}\text { Dry leaves } \\
\text { powder } \\
(5 \mathrm{~g} / 100 \mathrm{ml})\end{array}$ & $\begin{array}{l}50.8 \mathrm{~b} \\
(22.1)^{*}\end{array}$ & $\begin{array}{l}16.3 b \\
(23.5)\end{array}$ & $\begin{array}{l}3.4 \mathrm{ab} \\
(41.7)\end{array}$ & $\begin{array}{l}3.7 \mathrm{a} \\
(37.0)\end{array}$ & $\begin{array}{l}0.34 \mathrm{c} \\
(-)\end{array}$ & $\begin{array}{l}4 \mathrm{a} \\
(0.0)\end{array}$ & $\begin{array}{l}6.3 c \\
(16.7)\end{array}$ & $\begin{array}{l} \\
20.1\end{array}$ \\
\hline $\begin{array}{l}\text { Mashed fresh } \\
\text { leaves }(5 \mathrm{~g} / 100 \mathrm{ml})\end{array}$ & $\begin{array}{l}52.0 \mathrm{~b} \\
(25.0)\end{array}$ & $\begin{array}{l}14.5 \mathrm{c} \\
(9.8)\end{array}$ & $\begin{array}{l}3.0 \mathrm{bcd} \\
(25.0)\end{array}$ & $\begin{array}{l}3.9 \mathrm{a} \\
(44.4)\end{array}$ & $\begin{array}{l}0.34 \mathrm{c} \\
(-)\end{array}$ & $\begin{array}{l}4 \mathrm{a} \\
(0.0)\end{array}$ & $\begin{array}{l}7.7 \mathrm{~b} \\
(42.6)\end{array}$ & - \\
\hline $\begin{array}{l}\text { Seeds powder } \\
(5 \mathrm{~g} / 100 \mathrm{ml})\end{array}$ & $\begin{array}{l}56.2 \mathrm{a} \\
(35.1)\end{array}$ & $\begin{array}{l}18.9 \mathrm{a} \\
(43.2)\end{array}$ & $\begin{array}{l}3.3 \mathrm{abc} \\
(37.5)\end{array}$ & $\begin{array}{l}3.6 \mathrm{a} \\
(33.3)\end{array}$ & $\begin{array}{l}0.81 \mathrm{a} \\
(42.1)\end{array}$ & $\begin{array}{l}5 \mathrm{a} \\
(25.0)\end{array}$ & $\begin{array}{l}8.2 b \\
(51.9)\end{array}$ & - \\
\hline $\begin{array}{l}\text { Dry root powder } \\
(5 \mathrm{~g} / 100 \mathrm{ml})\end{array}$ & $\begin{array}{l}53.4 \mathrm{~b} \\
(28.4)\end{array}$ & $\begin{array}{l}19.1 \mathrm{a} \\
(44.7)\end{array}$ & $\begin{array}{l}2.7 \mathrm{~cd} \\
(11.1)\end{array}$ & $\begin{array}{l}4.3 \mathrm{a} \\
(59.3)\end{array}$ & $\begin{array}{l}0.74 \mathrm{a} \\
(29.8)\end{array}$ & $\begin{array}{l}5 \mathrm{a} \\
(25.0)\end{array}$ & $\begin{array}{l}9.5 \mathrm{a} \\
(75.9)\end{array}$ & - \\
\hline $\begin{array}{l}\text { Seed oil } \\
(5 \mathrm{ml} / 100 \mathrm{mlwater})\end{array}$ & $\begin{array}{l}53.2 \mathrm{~b} \\
(27.9)\end{array}$ & $\begin{array}{l}19.8 \mathrm{a} \\
(50.0)\end{array}$ & $\begin{array}{l}3.7 \mathrm{a} \\
(54.2)\end{array}$ & $\begin{array}{l}3.7 \mathrm{a} \\
(37.0)\end{array}$ & $\begin{array}{l}0.38 \mathrm{c} \\
(-)\end{array}$ & $\begin{array}{l}5 \mathrm{a} \\
(25.0)\end{array}$ & $\begin{array}{l}8.2 b \\
(51.9)\end{array}$ & - \\
\hline Control & $\begin{array}{l}41.6 \mathrm{c} \\
(0.0)\end{array}$ & $\begin{array}{l}13.2 \mathrm{~d} \\
(0.0)\end{array}$ & $\begin{array}{l}2.4 \mathrm{~d} \\
(0.0)\end{array}$ & $\begin{array}{l}2.7 \mathrm{~b} \\
(0.0)\end{array}$ & $\begin{array}{l}0.57 b \\
(0.0)\end{array}$ & $\begin{array}{l}4 \mathrm{a} \\
(0.0)\end{array}$ & $\begin{array}{l}5.4 \mathrm{~d} \\
(0.0)\end{array}$ & $\begin{array}{l}- \\
(0.0)\end{array}$ \\
\hline
\end{tabular}

Each value is an average of five replicates.

Different letter (s) of each column is significantly different according to Duncan's Multiple Range test at $\mathrm{p} \leq 0.05$ level.

Values between parentheses indicate the percentages increase of plant growth and yield criteria.

$*$ Increase (Inc.) $\%=$ Treated - Control X 100

Control

These compounds may dissolve the cytoplasmic membrane of nematode cells and their functional groups influencing the enzyme protein structure (Knoblock et al., 1989) They added that the extract's activity may be explained on this basis in nematode control. As shown by Khairy et al. (2021), moringa leaf powder significantly enhanced eggplant growth and suppressed nematode population. Saponins are considered a group of glycosidic secondary metabolites in aqueous leaf extracts of moringa (Khairy, 2016) which have been found to have nematicidal effect in vitro against Xiphinema index, $M$. incognita and Globodera rostochiensis (D'Addabbo et al., 2010). Besides, the reduction in population of root-knot nematode in soil and roots could be explained according to the ratio of carbon/ nitrogen $(\mathrm{C} / \mathrm{N})$ ratio) of the amendment of less than 20:1, causing more decomposition of the tested amendment in soil and consequently more effect on nematodes (Stirling 1991).The result conducted by Adiaha (2017) determined $\mathrm{C} / \mathrm{N}$ ratio to be 2.8:1 for moringa leaves that were proved as a good nutrient carrier of elements enhancing effective and productive cultivation of crops.

Also, the direct contact of the extracts and residues in soil to nematode juveniles of root-knot nematode, in addition to their active ingredients of potent substances can be effectively and directly delivered to the nematodes and may be responsible for their reduction and their inhibition in penetration into roots. The denaturation and 
degradation of nematode proteins influence on enzyme production and interference with the electron flow in respiratory chain. Adenosine diphosphate phosphorylation (ADP) may constitute a basis for interpreting the mode of action of plant extract (Konstantopoulou et al., 1994).The present results agreed with those obtained by Youssef and Lashein (2013), Youssef et al. (2015), and El-Nagdi and Youssef (2015) in controlling root-knot nematode, $M$. incognita by some medicinal plants residues and extracts. The organic materials when used in reducing the nematode population may be influenced by some factors from which complete teasing of plant tissues and mixing with soil, enough moisture required for decomposition in soil (Morra and Kierkegaard 2002) and suitable soil temperature at the time of addition (Ploeg and Stapleton 2001; López-Pérez et al. 2005).Also, the time of moringa leaf powder addition to soil affected nematode population as shown by Sowley et al. (2018), since when moringa was added, one week after planting cowpea in a field trial, it showed better results in suppressing galls of root-knot nematode and greater plant growth of cowpea compared to two and three weeks after planting. This may be due to that earlier treatment provided plants with essential nutrients, elements required for better growth and toxic substances for reducing nematodes. However, this method of application may cause disturbance to soil and plants during growth period. In our experiment, we added moringa tissues and extracts before planting pea in pots to ensure their decomposition in soil and absorption by plants and to avoid disturbance to soil and plants under screen house conditions.

\section{CONCLUSION}

It was worthy concluded that moringa residues with extracts significantly reduced reproduction and galling of root-knot nematode, $M$. incognita in roots, increased number of bacterial nodules which subsequently improved plant growth and yield of pea plants. Also, reduction in nematode may be induced by certain potent substances that found in moringa residues and extracts. The present study threw the light on the importance of some factors influencing the effect of moringa residues and further studies are needed to ascertain their efficacy on root- knot and other nematodes in the field.

\section{ACKNOWLEDGEMENTS}

The authors wish to express their grateful to Egyptian Society of Moringa, NRC, Dokki, Cairo, Egypt for providing the tested materials of moringa. Thanks are extended to Vegetable Research Institute, ARC, Dokki, Cairo, Egypt for providing seeds of field pea.

\section{REFERENCES}

Adiaha, M.S. (2017). Potential of Moringa oleifera as nutrient-agent for biofertilizer production. World News Nat. Sci., 10: 101-104

Anwar, F. and Rashid, U. (2007). Physico-chemical characteristics of Moringa oleifera seeds and seed oil from a wild provenance of Pakistan. Pak. J. Bot., 39(5): 1443-1453

Barker, K.R. (1985). Nematode extraction and bioassays. In: "An Advanced Treatise on Meloidogyne": Vol. II. Methodology (Barker K.R., Carter C.C., Sasser J.N., eds.). North Carolina State University, USA, 19-35 pp.

Claudius-Cole, A.O; Aminu, A.E. and Fawole, B. (2010). Evaluation of plant extracts in the management of root-knot nematode (Meloidogyne incognita) on cowpea (Vigna unguiculata (L) Walp). Mycopathologia 8:53-60.

D’Addabbo, T.; Laquale, S.; Perniola, M. and Candido, V. (2019). Biostimulants for plant growth promotion and sustainable management of phytoparasitic 
nematodes in vegetable crops. Agronomy 9 (10): 616. doi. org/ 10.3390/ agronomy 9100616

El-Nagdi, Wafaa M,A, and Youssef, M.M.A. (2015). Nematicidal effect of some aqueous extracts of botanicals and a commercial bacterial byproduct for biocontrolling root knot nematode, Meloidogyne incognita infecting sugar beet. Sci. Agric 10 (2): 55-58.

Jamil, A, Shahid, M.; Khan, M.M. and Ashraf, M. (2007). Screening of some medicinal plants for isolation of antifungal proteins and peptides. Pak J. Bot. 39 (1): 211-221.

Jasy, T. and Koshy, P. K. (1992). Effect of certain plant extracts and Gliricidia maculate (H.B\&K) Stend as green manure on Radopholus similis. Ind. J. Nematol. 22:117-121

Kebreab, A.G.; Gunaratna, K.R.; Henriksson, H.; Brumer, H. and Dalhammar, G. (2005). A simple purification and activity assay of the coagulant protein from Moringa oleifera seed. Water Res. 39(11): 2338-2344.

Khairy, Doaa M. (2016). Management of root-knot nematode Meloidogyne incognita by the use of certain bioagents. M.Sc. Thesis, Fac. Agric., Mansoura Univ., Egypt, 110pp.

Khairy, Doaa M.; Refaei, A.R. and Mostafa, Fatma, A.M. (2021). Management of Meloidogyne incognita infecting eggplant using moringa extracts, vermicompost, and two commercial bio-products. Egypt. J. Agronematol. 20(1): 1-16 (DOI:10.21608/EJAJ.2021.134910

Knoblock, K.; Pauli, A.; Iberl, B.; Weigand, H. and Weis, N. (1989). Antibacterial and antifungal properties of essential oil components. J. Essen. Oil Res. $1: 119-128$.

Konstantopoulou, I.; Vassilopoulou, L.; Mawogantisi, P.P. and Scouras, G. (1994). Insecticidal effect of essential oils: a study of essential oils extracted from eleven Greek aromatic plants on Drosophila auroria. Experientia, 48: 616619 .

Lockett, C.T.; Calvet, C.C. and Grivetti, L.E. (2000). Energy and micronutrient composition of dietary and medicinal wild plants consumed during drought. Study of rural Fulani, northeastern Nigeria. Int. J. Food Sci. Nutr.51 (3):195208

López-Pérez, J.A.; Roubtsova, T. and Ploeg, A. (2005). Effect of three plant residues and chicken manure used as biofumigants at three temperatures on Meloidogyne incognita infestation of tomato in greenhouse experiments. J. Nematol. 37: 489-494 .

Morra, M.J. and Kirkegaard, J.A. (2002). Isothiocyanate release from soil incorporated Brassica tissues. Soil Biol. Biochem. 34: 1683-1690.

Ploeg, A.T. and Stapleton, J.J. (2001). Glasshouse studies on the effects of time, temperature and amendment of soil with broccoli plant residues on the infestation of melon plants by Meloidogyne incognita and M. javanica. Nematology 3: 855-861.

Ramadan, Walaa A. and Soliman, Gazeia M. (2020). Effect of different applications of bio-agent Achromobacter xylosoxidans against Meloidogyne incognita and gene expression in infected eggplant. Jordan J. Biol. Sci. 13(3): 363 -370.

Snedecor, G.W. and Cochran, W.G. (1989). Statistical Methods. 8th ed. Ames, Iowa: Iowa State University Press .

Sowley, E.N.K.; Kankam, F and Adomako J. (2014). Management of root- knot nematode (Meloidogyne spp.) on sweet pepper (Capsicum annuum L.) with 
moringa (Moringa oleifera Lam.) leaf powder. Arch. Phytopathol. Plant Prot. 47(13):1531-1538.

Sowley, E.N.K.; Kankam, F. and Dasmana, H. (2018). Effect of time of application of moringa (Moringa oleifera Lam.) leaf powder on root-knot nematode (Meloidogyne spp.) infecting cowpea (Vigna unguiculata L. Walp). Adv. Agric. Sci. 6(4):32-41.

Stirling, G.R. (1991). Biological Control of Plant Parasitic Nematodes: Progress, Problems and Prospects. Wallingford, Oxon, UK: CAB International.

Young, T.W. (1954). An incubation method for collecting migratory- endoparasitic nematodes. Plant Dis. Reptr. 38 (11):794-79.

Youssef, M.M.A. and Lashein Asmahan M.S. (2013). Efficacy of different medicinal plants as green and dry leaves and extracts of leaves on root knot nematode, Meloidogyne incognita infecting eggplant. Eur. J. Agric. Environ. Med. 2(1):10-14 .

Youssef, M.M.A.; El-Nagdi, Wafaa M.A. and Dawood, Mona G. (2015). Population density of root-knot nematode, Meloidogyne incognita infecting eggplant as affected by medicinal plant aqueous extracts. Appl. Sci. Reptr. 10(1):8-11.

$$
\text { الملخص العربى }
$$

\section{مكافحة نيماتوداتعقد الجذور Meloidogyne incognita على نبات البازلاء الجافة الحقلية بواسطة بعض مستخلصات وبقايا نبات المورينجا

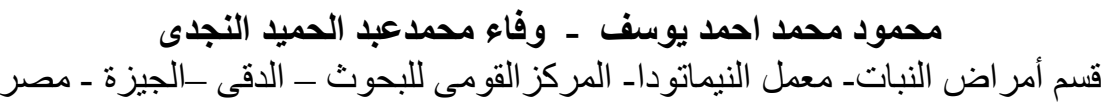

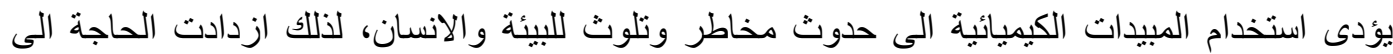

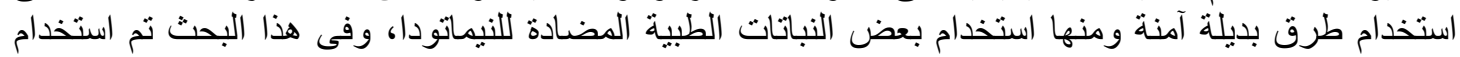
اجز اء معينة من نبات المورينجا كبقايا نباتية ومستخلصاتهالمائية وزيت وليت البذرة لمكافحة نيماتودا تعقد الجذور Meloidogyne incognita النسب المئوية الكلية للإنخفاض فى قراءات النيماتودا لكل متغير، وجد أن مسحوق الجذور الجافة سجل أعلى

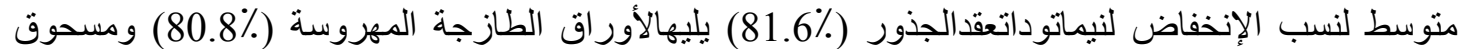

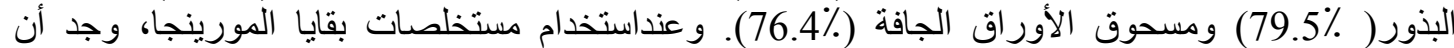
المستخلص المائي لمسحوق البذور حقق أعلى نسبة نقص للنيماتودا (81.1\%) يليه مستخلص مسحوق الأوراق الجافة (80.8\%) ، مستخلص مسحوق الجذر الجاف (80.5\%).وكان اقل نقص فى اعداد النيماتودا (84.2\%) بو اسطة زيت البذرة. كذللك ادت المعاملات الى نقص عدد العقد النيماتودية وزيادة عدد العقد البكتيرية طبقا للمو اد المستخدمة. ونتيجة لذلك ادت المعاملات الى تحسين النمو الخضرى ومحصول نبات الباز لاءالجافة.

الكلمات الدالة: المكافحةالحيوية، ميلويدوجين انكوجنيتا ،مسنخلصات وبقايا نبات المورينجا، نبات البازلاء 